\title{
Two New Species of Parastenocaris (Copepoda, Harpacticoida) from a Hyporheic Zone and Overview of the Present Knowledge on Stygobiotic Copepoda in Vietnam ${ }^{\dagger}$
}

\author{
Ngoc-Son Tran $1, *, \ddagger$, Mau Trinh-Dang $1, \ddagger(\mathbb{D}$ and Anton Brancelj $2,3, \ddagger$ \\ 1 Faculty of Biology and Environmental Sciences, The University of Danang-University of Science and \\ Education, 459 Ton Duc Thang St., Danang City 550000, Vietnam; tdmau@ued.udn.vn \\ 2 National Institute of Biology, Večna pot 111, 1000 Ljubljana, Slovenia; Anton.Brancelj@nib.si \\ 3 Faculty of Environmental Sciences, University of Nova Gorica, Vipavska cesta 13, 5000 Nova Gorica, Slovenia \\ * Correspondence: tnson@ued.udn.vn or tranngocsondhsp@gmail.com; Tel.: +84-973-065-083 \\ † urn:lsid:zoobank.org:pub:606EA9AB-1C69-4C24-8B2F-53CDD4A87B93. \\ ‡ urn:lsid:zoobank.org:author: A38AA3C8-2EC2-4CF2-AA6D-B45779D8CE8D (N.-S.T.), \\ urn:lsid:zoobank.org:author: 1F57CA50-EF80-4031-BDD1-AC8EB712AF07 (M.T.-D.), \\ urn:lsid:zoobank.org:author: 9A625D83-B9D4-4687-ADBF-E0E3552ACDC7 (A.B.).
}

check for updates

Citation: Tran, N.-S.; Trinh-Dang, M.; Brancelj, A. Two New Species of Parastenocaris (Copepoda, Harpacticoida) from a Hyporheic Zone and Overview of the Present Knowledge on Stygobiotic Copepoda in Vietnam. Diversity 2021, 13, 534. https://doi.org/10.3390/d13110534

Received: 21 September 2021

Accepted: 20 October 2021

Published: 25 October 2021

Publisher's Note: MDPI stays neutral with regard to jurisdictional claims in published maps and institutional affiliations.

Copyright: (C) 2021 by the authors. Licensee MDPI, Basel, Switzerland. This article is an open access article distributed under the terms and conditions of the Creative Commons Attribution (CC BY) license (https:// creativecommons.org/licenses/by/ $4.0 /)$.

\begin{abstract}
The number of freshwater species belonging to the genus Parastenocaris reported from ten countries of Southeast Asia is quite limited. Only two species have been reported so far from freshwater habitats there, compared to over 290 described species of the family Parastenocarididae worldwide. During the first study of the hyporheic zone of two small rivers in central Vietnam, two new species of the family Parastenocarididae were collected, Parastenocaris sontraensis sp. nov. and Parastencaris vugiaensis sp. nov. Both were collected from the gravel bar along the rivers (Suoi Da and $\mathrm{Vu}$ Gia river) using the Karaman-Chappuis method. Both the new species belong to the brevipes group of the genus Parastenocaris Kessler, 1913 sensu Lang (1948), and Reid (1995). Parastenocaris sontraensis sp. nov. is similar to P. hinumaensis Kikuchi, 1970 and Parastenocaris jane Karanovic, 2006 in the brevipes-group. Parastenocaris sontraensis sp. nov. differs from both Parastenocaris species by (i) Exp P3 with three segments in the male, (ii) caudal rami with seven setae, and (iii) caudal rami about 2.4 times as long as wide. Parastencaris vugiaensis sp. nov. can be distinguished from its congeners by the unique combination of the following characters: (i) the elliptical shape of caudal rami, (ii) apical seta (V) with bulbous base, and (iii) anal operculum extends beyond the end of anal somite. Until now, 14 stygobiotic species of Copepoda have been recorded in Vietnam (including two new species in this paper), which is relatively few compared with nearby Thailand with 25 species. Short comments on other stygobiotic Copepoda from Vietnam are added.
\end{abstract}

Keywords: Southeast Asia; groundwater fauna; hyporheic zone; Copepoda; new species; taxonomy

\section{Introduction}

Southeast Asia contains hot spots of biodiversity, with the catchment area of Mekong river at its centre. In recent times, several new species of mammals, amphibians, fish, and different aquatic animals have been recorded there, including from Vietnam [1].

In Vietnam, the known number of stygobiotic Copepoda (i.e., strict groundwaterdwelling species) is still quite limited, although the number of species increased significantly-from five species before 2010 to twelve at present (Table 1). This is still rather low compared to 25 stygobiotic copepods species from Thailand, which is among the best-investigated country in the region $[2,3]$. So far, 3 species of stygobiotic Calanoida have been recorded in Vietnam (Hadodiaptomus dumonti Brancelj, 2005; Nannodiaptomus phongnhaensis Dang and Ho, 2001; N. haii Tran and Brancelj, 2017) out of 12 known worldwide. This number indicates the high potential for stygofauna there, not only among Copepoda 
but other groups, too. At the same time, most stygobiotic species recorded so far have been from fractured (i.e., karstic) habitats (caves and springs [2,3], while interstitial habitats (i.e., habitats in unconsolidated sediments) along the rivers have not been studied at all.

Table 1. List of stygobiotic Copepoda in Vietnam.

\begin{tabular}{|c|c|c|}
\hline Taxa & Habitat & Location \\
\hline \multicolumn{3}{|l|}{ Calanoida } \\
\hline Hadodiaptomus dumonti Brancelj, 2005 & Cave & $\begin{array}{c}\text { Dang water cave, Cuc Phuong National } \\
\text { Park, Ha Noi }\end{array}$ \\
\hline Nannodiaptomus phongnhaensis Dang and Ho, 2000 & Cave & $\begin{array}{l}\text { Phong Nha cave, Phong Nha-Ke Bang } \\
\text { National Park, Quang Binh province }\end{array}$ \\
\hline Nannodiaptomus haii Tran and Brancelj, 2017 & Cave & $\begin{array}{l}\text { Hang Toi Cave, Phong Nha-Ke Bang } \\
\text { National Park, Quang Binh province }\end{array}$ \\
\hline \multicolumn{3}{|l|}{ Cyclopoida } \\
\hline Bryocyclops anninae (Menzel 1926) & Cave & $\begin{array}{l}\text { Thien Duong cave, Phong Nha-Ke Bang } \\
\text { National Park, Quang Binh province }\end{array}$ \\
\hline Pseudograeteriella longifurcata (Tran and Chang, 2012) & Cave & $\begin{array}{l}\text { Thien Duong cave, Phong Nha-Ke Bang } \\
\text { National Park, Quang Binh province }\end{array}$ \\
\hline $\begin{array}{c}\text { Pseudograeteriella longiaesthetascus Sanoamuang, } \\
\text { Boonyanusith and Brancelj, } 2019\end{array}$ & Cave & $\begin{array}{l}\text { Thien Duong cave, Phong Nha-Ke Bang } \\
\text { National Park, Quang Binh province }\end{array}$ \\
\hline Mesocyclops sondoongensis Tran and Hołynska, 2015 & Cave & Son Dong cave, Quang Binh province \\
\hline Metacyclops amicitiae Kołaczynski, 2015 & Hyporheic & Tam Dao district, Vinh Phuc province \\
\hline \multicolumn{3}{|l|}{ Harpacticoida } \\
\hline Attheyella (Canthosella) vietnamica Borutzky, 1967 & Cave & Lac Thuy district, Hoa Binh province \\
\hline Elaphoidella vietnamica Borutzky, 1967 & Cave & Lac Thuy district, Hoa Binh province \\
\hline Microarthridion thanhi Tran and Chang, 2013 & Anchialine cave & $\begin{array}{c}\text { Son Duong cave, and Ba Giot cave, Ninh } \\
\text { Binh province }\end{array}$ \\
\hline Nitocra vietnamensis Tran and Chang, 2013 & Cave & $\begin{array}{c}\text { Son Duong cave, and Ba Giot cave, Ninh } \\
\text { Binh province }\end{array}$ \\
\hline
\end{tabular}

Until now, over 290 species and subspecies belonging to the family Parastenocarididae have been reported worldwide [4], of which only three have been recorded from freshwater habitats in Southeast Asia. One species has been reported from the Philippines and one from Malaysia [2]. Representatives of the family Parastenocarididae can be found exclusively in subterranean habitats, both in fractured (karstic) as well as interstitial (unconsolidated) aquifers, with prevalence in interstitial habitats [5].

Between 2019 and 2020, within the project "Research on diversity of copepods in groundwater for indicating the environmental quality of water in Quang Nam province and Da Nang City", intensive sampling of a hyporheic zone from two small rivers in the central part of Vietnam revealed several new groundwater-dwelling harpacticoid species, two of them described hereafter. Both species belong to the subfamily Parastenocarididae Chappuis, 1940. This is the first record of the genus Parastenocaris Kessler, 1913 in Vietnam.

\section{Materials and Methods}

Samples were collected from a hyporheic zone of two small rivers (mean annual discharge $<5 \mathrm{~m}^{3} \mathrm{~s}^{-1}$ ): Suoi Da stream located on Son Tra peninsula next to Da Nang city and Vu Gia river in the Quang Nam province in the central part of Vietnam in June 2019 (for details see "type locality" section). A hole $100 \mathrm{~cm}$ in diameter and about $25 \mathrm{~cm}$ deep (i.e., Karaman-Chappuis method-KC pit-hole) [6] was dug in a gravel bar next to the river. About $10 \mathrm{~L}$ of water was filtered through a specially designed filtering bottle fitted with $60 \mu \mathrm{m}$ mesh size [7]. Samples were put in a $4 \%$ formaldehyde solution and 
brought into a laboratory where specimens were sorted. Before dissection, animals were put into a mixture of glycerol and 70\% alcohol (ratio 1:1) and replaced within $20 \mathrm{~min}$ with pure glycerol. Dissection was performed at $100 \times$ magnification (508 Carl Zeiss stereomicroscope). Examination of all body parts was performed under magnification of 1000× (Axio Lab A1 Carl Zeiss compound microscope), except for the female/male habitus, which was examined at $400 \times$ magnification. All drawings were made using the Inkscape graphic program ver. 1.1 [8].

The following abbreviations are used throughout the text and figures: Enp = endopod; Exp = exopod; Exp/Enp-1 = proximal segment; Exp/Enp-2 = middle segment; Exp/Enp-3 = distal segment; legs = P1-P6. The nomenclature and descriptive terminology follow those of [9].

Basic environmental parameters (water temperature (WT), $\mathrm{pH}$, dissolved oxygen (DO), and electrical conductivity (EC)) were measured in situ using the YSI 6920V2 Sonde water quality monitoring system (YSI Incorporated, USA). Nitrate $\left(\mathrm{NO}_{3}-\mathrm{N}\right)$ and phosphate $\left(\mathrm{PO}_{4}-\mathrm{P}\right)$ were determined in the laboratory according to standard methods [10]. Environmental parameters are presented in Table 2.

Table 2. Environmental parameters in a hyporheic zone of two rivers in the central Vietnam in June 2019.

\begin{tabular}{ccc}
\hline Parameters & Suoi Da Stream & Vu Gia River \\
\hline $\mathrm{WT}\left({ }^{\circ} \mathrm{C}\right)$ & 24.5 & 22.1 \\
\hline $\mathrm{pH}$ & 6.0 & 6.3 \\
\hline $\mathrm{DO}(\mathrm{mg} / \mathrm{L})$ & 3.76 & 5.12 \\
\hline $\mathrm{EC}(\mu \mathrm{S} / \mathrm{cm})$ & 60 & 176 \\
\hline $\mathrm{NO}_{3}-\mathrm{N}(\mathrm{mg} / \mathrm{L})$ & 0.25 & 0.13 \\
\hline $\mathrm{PO}_{4}-\mathrm{P}(\mathrm{mg} / \mathrm{L})$ & 1.10 & 1.63 \\
\hline
\end{tabular}

\section{Results}

Subclass Copepoda Milne Edwards, 1830

Order Harpacticoida Sars, 1903

Family Parastenocarididae Chappuis, 1940

Genus Parastenocaris Kessler, 1913

Type species Parastenocaris brevipes Kessler, 1913

\subsection{Parastenocaris sontraensis $\mathrm{sp}$. nov.}

Type locality. Groundwater on the bank of Suoi Da stream, Son Tra peninsula, Da Nang city; central Vietnam; $16^{\circ} 06^{\prime} 50.9^{\prime \prime} \mathrm{N} 108^{\circ} 15^{\prime} 20.6^{\prime \prime}$ E.

Material examined. Holotype: adult female (total length $303 \mu \mathrm{m}$ ), completely dissected, mounted on one slide; collected on 8 June 2019 from KC pit-hole on the bank of Suoi Da stream; deposited in the Zoological Collection of Duy Tan University, Da Nang City, Vietnam; access No.: ZC-DTU-COPEPODA-0001. Allotype: male completely dissected, mounted on one slide; collected on the same date and same location as holotype; access No.: ZC-DTU-COPEPODA-0002. Paratypes: 15 females, 12 males; stored in a plastic tube in $70 \%$ alcohol; collected on the same date and same location as holotype and allotype; access No.: ZC-DTU-COPEPODA-0003. Additional material: 2 females, 2 males; stored in a plastic tube in $70 \%$ alcohol in the lead author's collection at the Faculty of Biology and Environmental Science, The University of Danang, University of Science and Education.

Etymology. The new species is named after Son Tra peninsula, a place where it was found for the first time. The name is in the nominative singular, gender masculine.

Description. Female, body length, measured from anterior margin of rostrum to posterior margin of caudal rami, 273-366 $\mu \mathrm{m}$ (mean $=316 \mu \mathrm{m}, n=6$ ). Habitus cylindrical, compressed dorsoventrally; prosoma/urosoma length ratio about 0.8 ; greatest width at fourth pedigerous somite; preserved specimens colourless (Figure 1A). Naupliar eye and 
hyaline integumental window absent. Posterior margins of prosomites and urosomites smooth dorsally (Figure 1A,B). Genital double-somite as long as wide. Genital complex (Figure 1C) with paired genital aperture; copulatory pore located anteriorly between genital apertures, poorly sclerotized, broadly rounded; seminal receptacles small, ovoid and simple. Anal somite symmetrical, about 1.2 times as long as wide. Operculum well developed, with slightly convex free margin, not reaching distal end of anal somite, with a row of setules close to free margin dorsally.

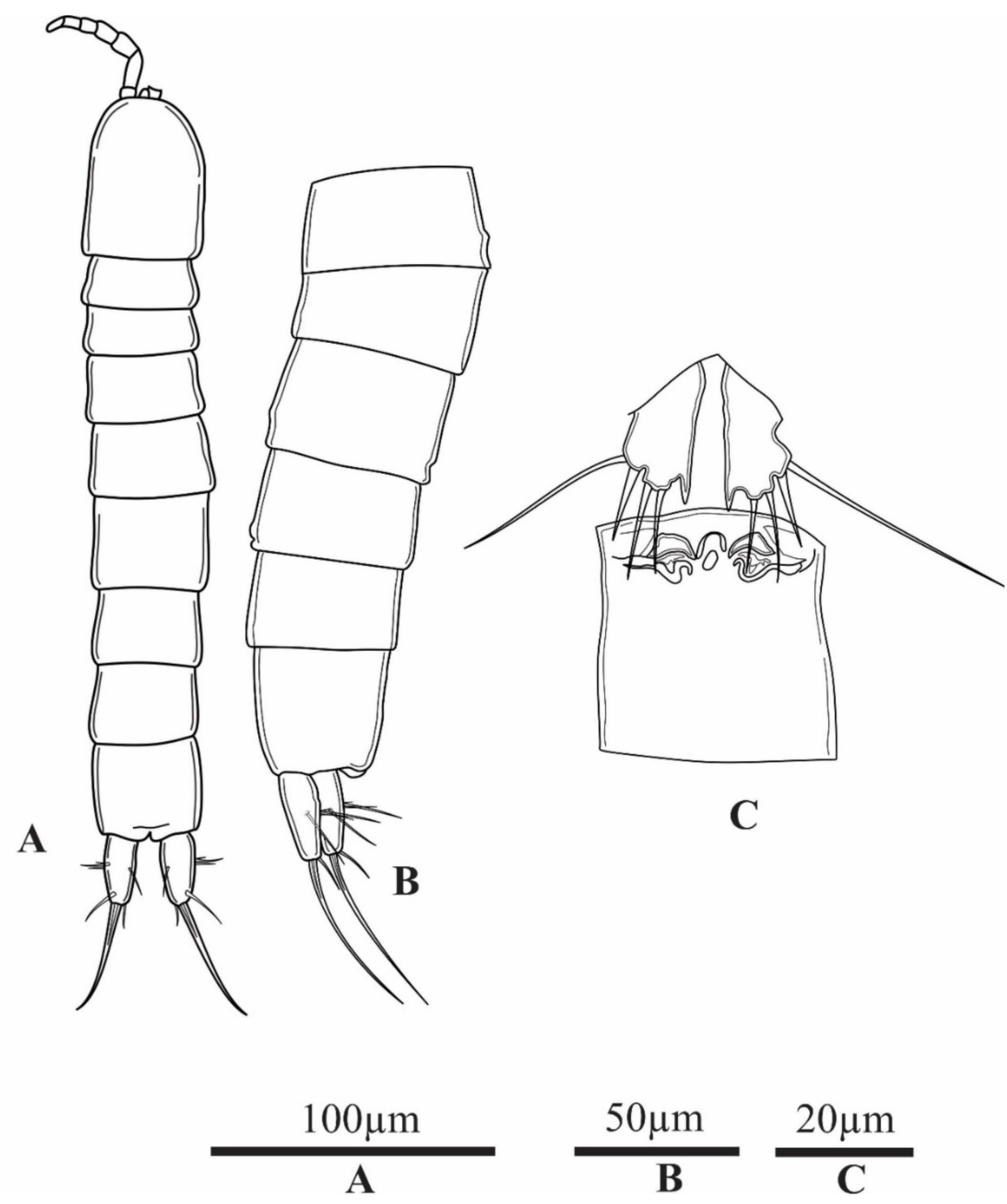

Figure 1. Parastenocaris sontraensis sp. nov. holotype female. (A), habitus dorsal view; (B), urosome lateral view; (C), P5 and P6 and genital complex.

Caudal rami (Figure 2A,B) conical, slightly diverging, with a row of spinules along dorsal side; each ramus about 2.4 times as long as wide. Anterolateral accessory seta (I) inserted at half the length of caudal ramus, short, about 0.6 length of anterolateral external accessory seta (II), positioned next to it and as long as width of caudal ramus. Anterolateral accessory seta (III) positioned close to seta II, smooth, about 1.5 times as long as seta II. Outer apical seta (IV) approximately as long as caudal ramus, pinnate, robust. Apical seta (V) long, smooth, about 4.5 times as long as caudal ramus, without breaking plane. Inner accessory seta (VI) about $1 / 2$ length of outer apical seta, soft, smooth. Dorsal seta (VII) as long as caudal ramus, inserted at half-length of caudal ramus, bi-articulated. 


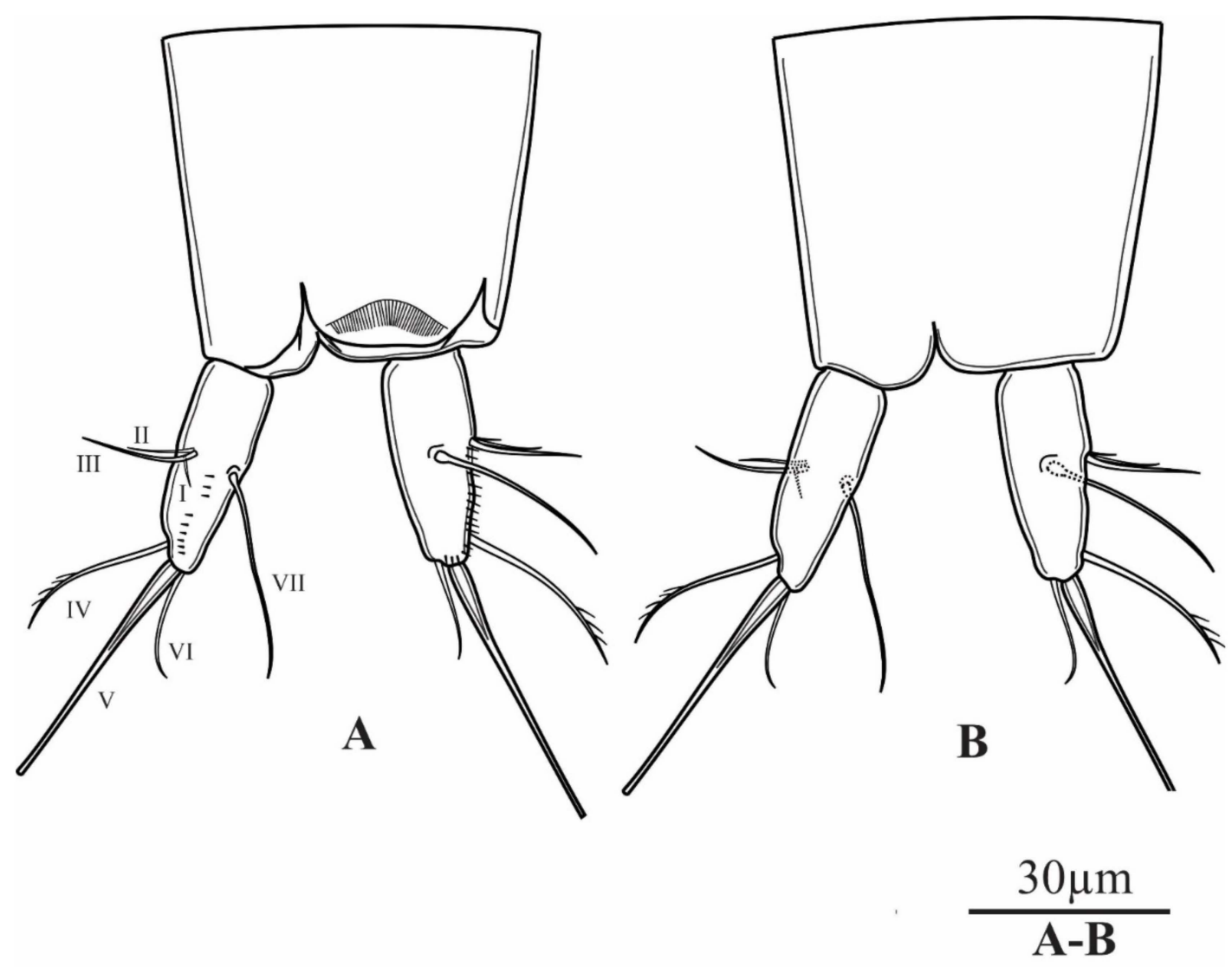

Figure 2. Parastenocaris sontraensis sp. nov. holotype female. (A), anal somite with furcal rami dorsal view; (B), anal somite with furcal rami ventral view.

Antennule (Figure 3A) 7-segmented, not reaching posterior margin of cephalothorax. Aesthetasc on fourth segment, reaching beyond tip of appendage and longer than apical aesthetasc on seventh segment. Setal formula: 0.4.3.2+ ae.1.0.9 + ae.

Antenna (Figure 3B) with allobasis about 2.4 times as long as wide; small, 1-segmented Exp with one bi-pinnate seta apically. Enp shorter than allobasis, with one outer strong spine medially; several small spinules at proximal part of segment, apically with five elements: two geniculate setae, two smooth setae, one bifurcate spiniform seta; with one spine sub-apically.

Mandible (Figure 4A) with three chitinised teeth on the cutting edge. Mandibular palp short, 1-segmented; apically with two thin and smooth setae.

Maxillule (Figure 4B) 1-segmented; praecoxal arthrite with three claw-like spines and one curved spine sub-apically; coxal endite with one curved seta; basis with two smooth setae.

Maxilla (Figure 4C) 2-segmented; syncoxa with two endites, proximal one long, armed with one seta apically, distal endite armed with two unequal setae apically. Basis drawn out into strong claw. Enp elongated, with two setae unequal in length.

Maxiliped (Figure 4D) with strong syncoxa, unornamented and unarmed. Basis slender, about 4 times as long as wide, with a row of long spinules along distal inner margin. Enp represented by short straight claw, swollen at base, about 0.9 times as long as its basis, bare.

P1-P4 (Figures 5B, 6A,B, 8B,C and 9A) coxa and intercoxal sclerite of all legs smooth and unarmed. 

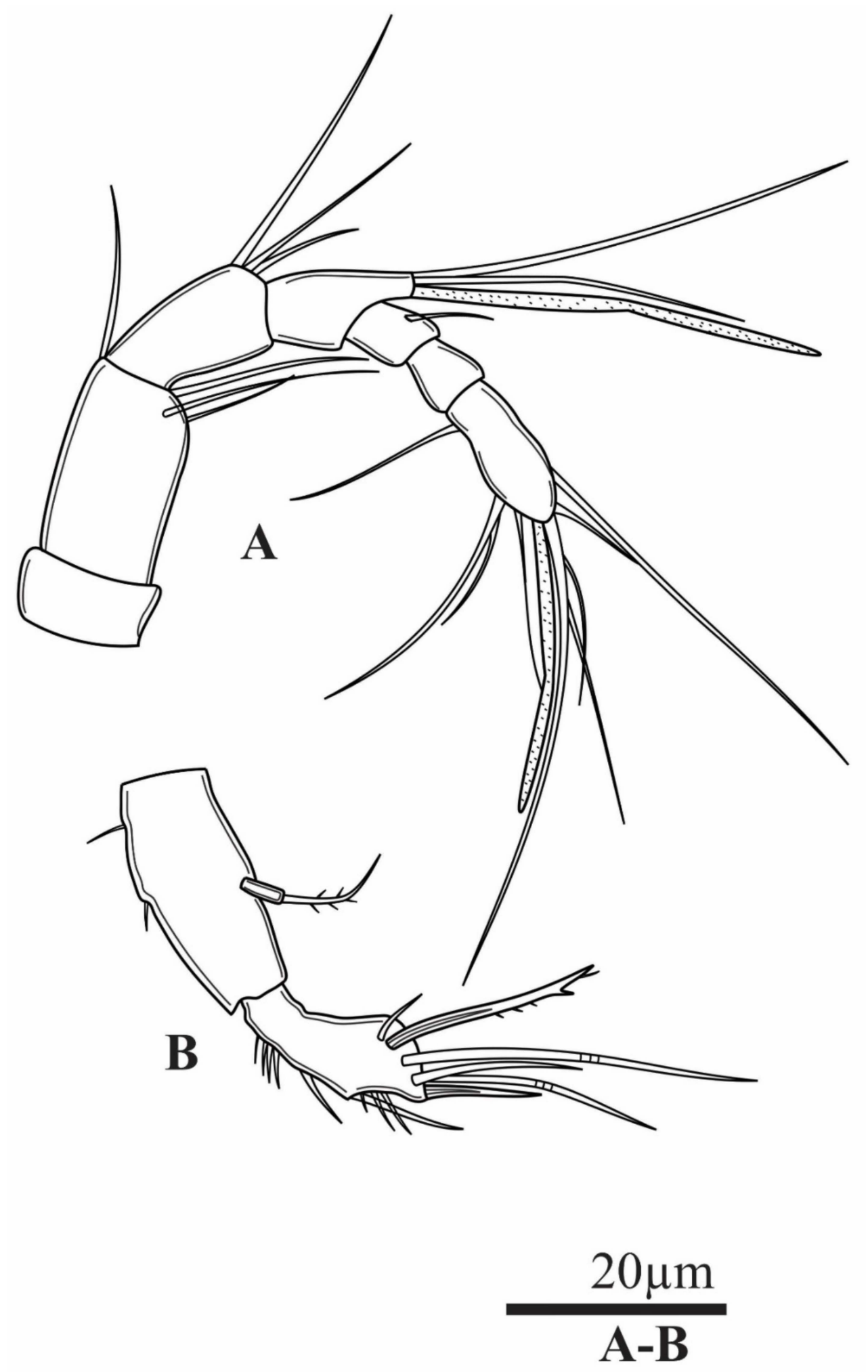

Figure 3. Parastenocaris sontraensis sp. nov. holotype female. (A), antennule; (B), antenna. 


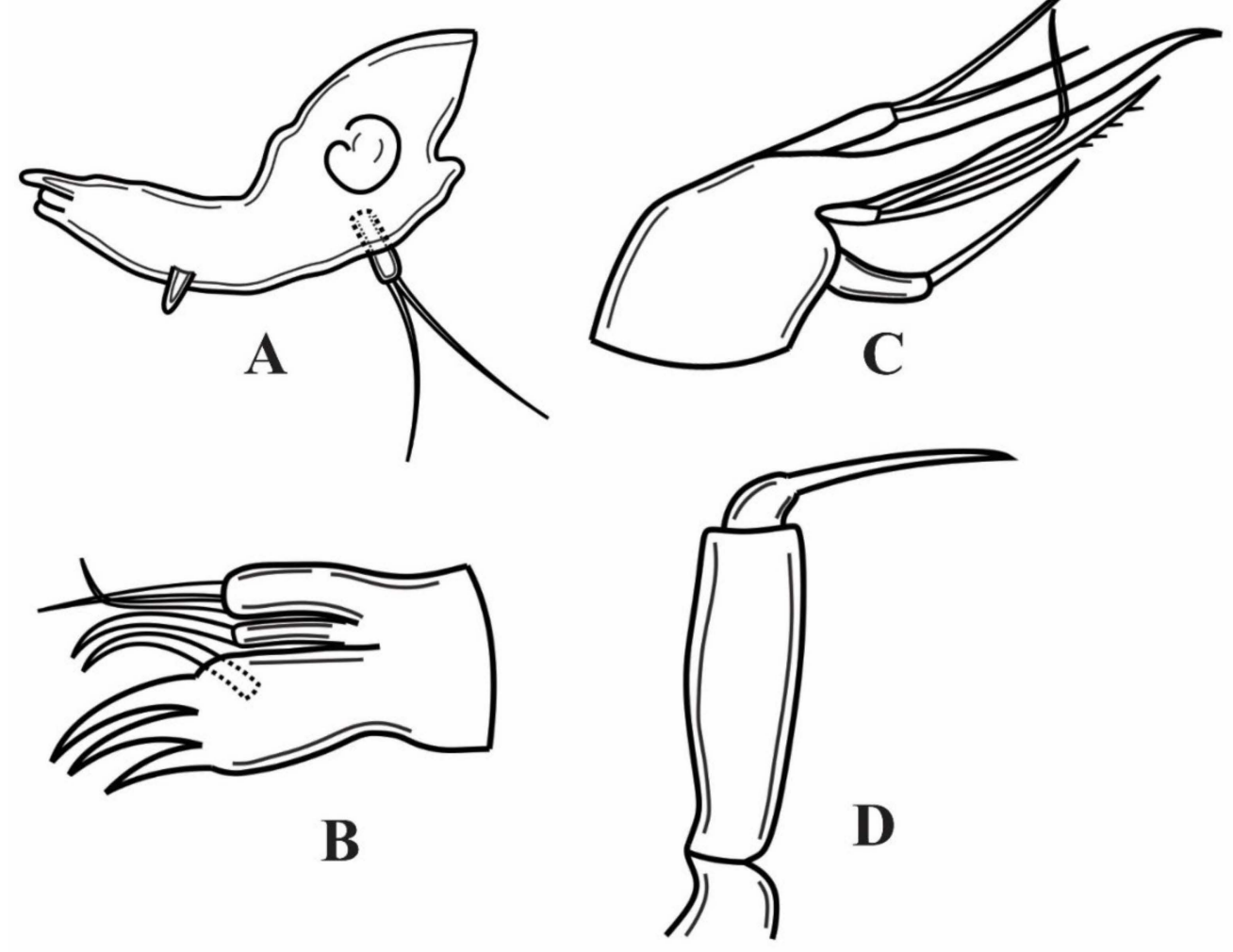

$30 \mu \mathrm{m}$

\section{A-D}

Figure 4. Parastenocaris sontraensis sp. nov. holotype female. (A), mandible; (B), maxillule; (C), maxilla; (D), maxilliped.

P1 (Figure 5A) basis with three rows of anterior spinules, two close to insertion of Exp and Enp, third one medially, close to outer margin; inner seta present. Exp 3-segmented, Enp 2-segmented; Exp as long as Enp. Enp-1 with two outer short rows of fine spinules. Enp-2 with two elements apically, one long geniculate seta, and one spine. Exp-1 about 2.5 times as long as wide, with one strong outer spine at $\frac{3}{4}$ of its length. Exp-2 without outer spine or seta, about 1.2 times as long as wide. Exp-3 about twice as long as wide, with four elements: one strong outer spine sub-apically, one strong uni-pinnate spine, and two long geniculate setae apically, longest geniculate seta longer than Exp.

P2 (Figure 5B) coxa elongated. Basis with three outer spinules, without outer seta; Exp 3-segmented, Enp 1-segmented. Enp about 5.7 times as long as wide, with four elements apically: three short spiniform spinules qual in length and one long smooth seta. Exp-1 about 3.5 times as long as wide, with several long and robust outer spinules; sub-apically, a long outer spine, reaching beyond Exp-2. Exp-2 about 2.3 times as long as wide, with a distal row of outer spinules. Exp-3 slightly longer than Exp-2, with one outer spine, accompanied by a group of spinules: one inner short spinule sub-distally; one sub-distal outer pinnate spine; apically, one bi-pinnate seta.

P3 (Figure 6A) coxa trapezoidal. Basis with one long, thin smooth outer seta. Exp 2-segmented, Enp represented by a strong smooth spine, Enp about 0.8 length of Exp-1. Exp-1 similar to Exp-1 of P2. Exp-2 with one short outer spinule at $\frac{3}{4}$ length of margin; one short inner spinule, one unilaterally pinnate outer seta apically and one spiniform unilaterally pinnate seta sub-apically. 


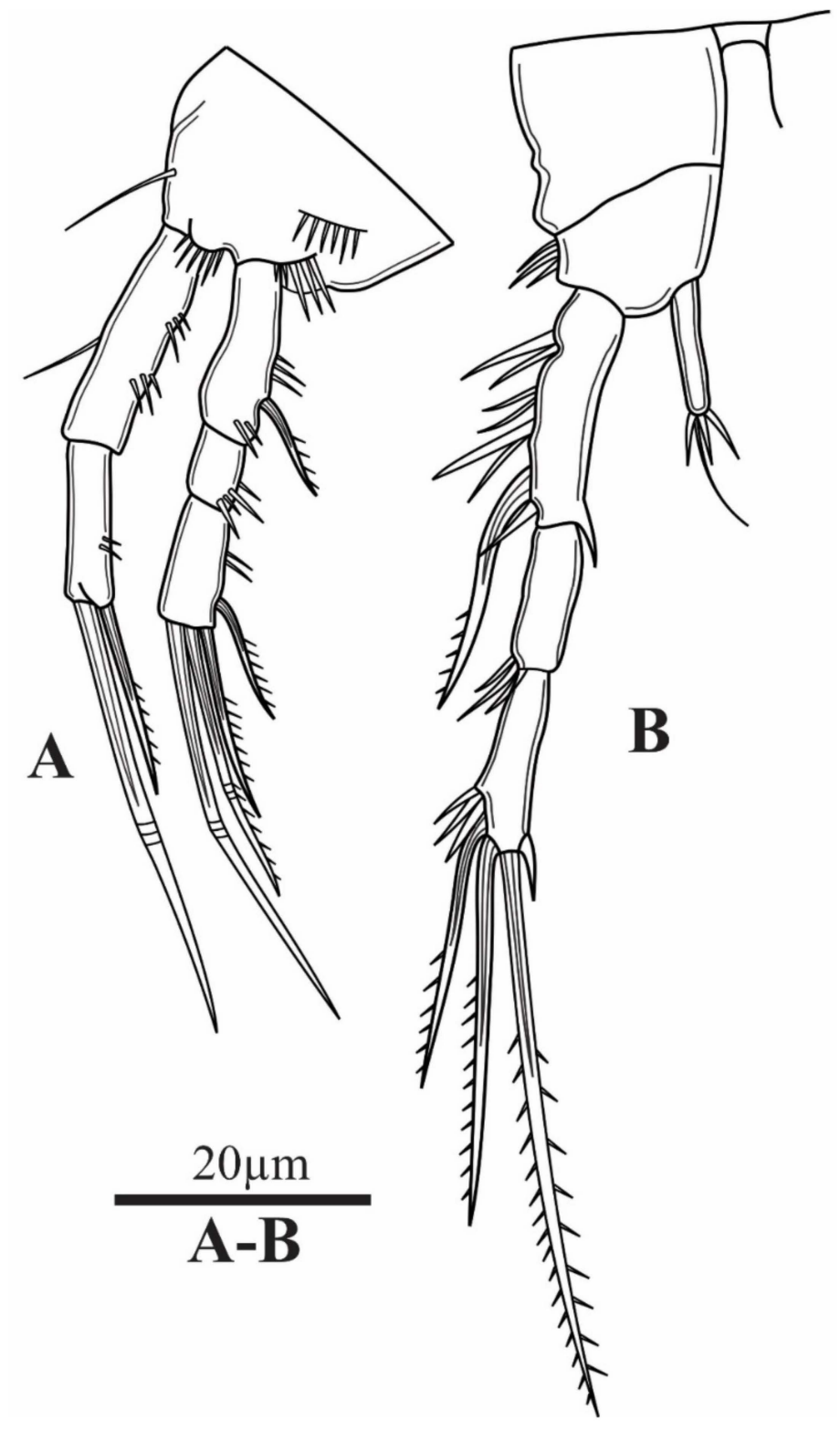

Figure 5. Parastenocaris sontraensis sp. nov. holotype female. (A), P1; (B), P2.

P4 (Figure 6B) coxa trapezoidal. Basis with one thin, short, and smooth outer seta accompanied with few spinules. Exp 3-segmented, Enp 1-segmented. Enp about 0.6 times as long as Exp-1, with one bi-pinnate seta apically. Exp-1 similar to Exp-1 of P3. Exp-2 similar to Exp-2 of P2. Exp-3 with two uni-pinnate spiniform setae apically; outer seta 0.5 length of inner seta; inner seta about 1.5 length of segment bearing it.

P5 (Figure 1C) with baseoendopod trapezoidal, with four setae along margin; outer one the longest, about 6 times as other three inner setae sub-equal in length; all setae soft, unornamented. Inner distal corner produced into sharp pointed outgrowth.

P6 (Figure 1C) fused to the somite, small, forming simple plate, unornamented and unarmed.

Description. Male; body length, measured from anterior margin of rostrum to posterior margin of caudal rami, 267-369 $\mu \mathrm{m}$ (mean $=317 \mu \mathrm{m}, n=6)$. Habitus cylindrical, compressed dorsoventrally; prosoma / urosoma length ratio $=0.8$; greatest width at $2 / 3$ length of cephalothorax; preserved specimens colourless (Figure 7A). Naupliar eye and hyaline integumental window absent. Rostrum small, triangular, no sensila observed. Posterior margins of prosomites and urosomites smooth dorsally (Figure 7A,B). Anal somite 
(Figure 7C) about 1.2 times as long as wide. Operculum well developed, with slightly convex free smooth margin, not reaching distal end of anal somite; with row of setules. Rostrum, mouthparts, caudal rami, antenna, P1 and P2 similar to those of female.

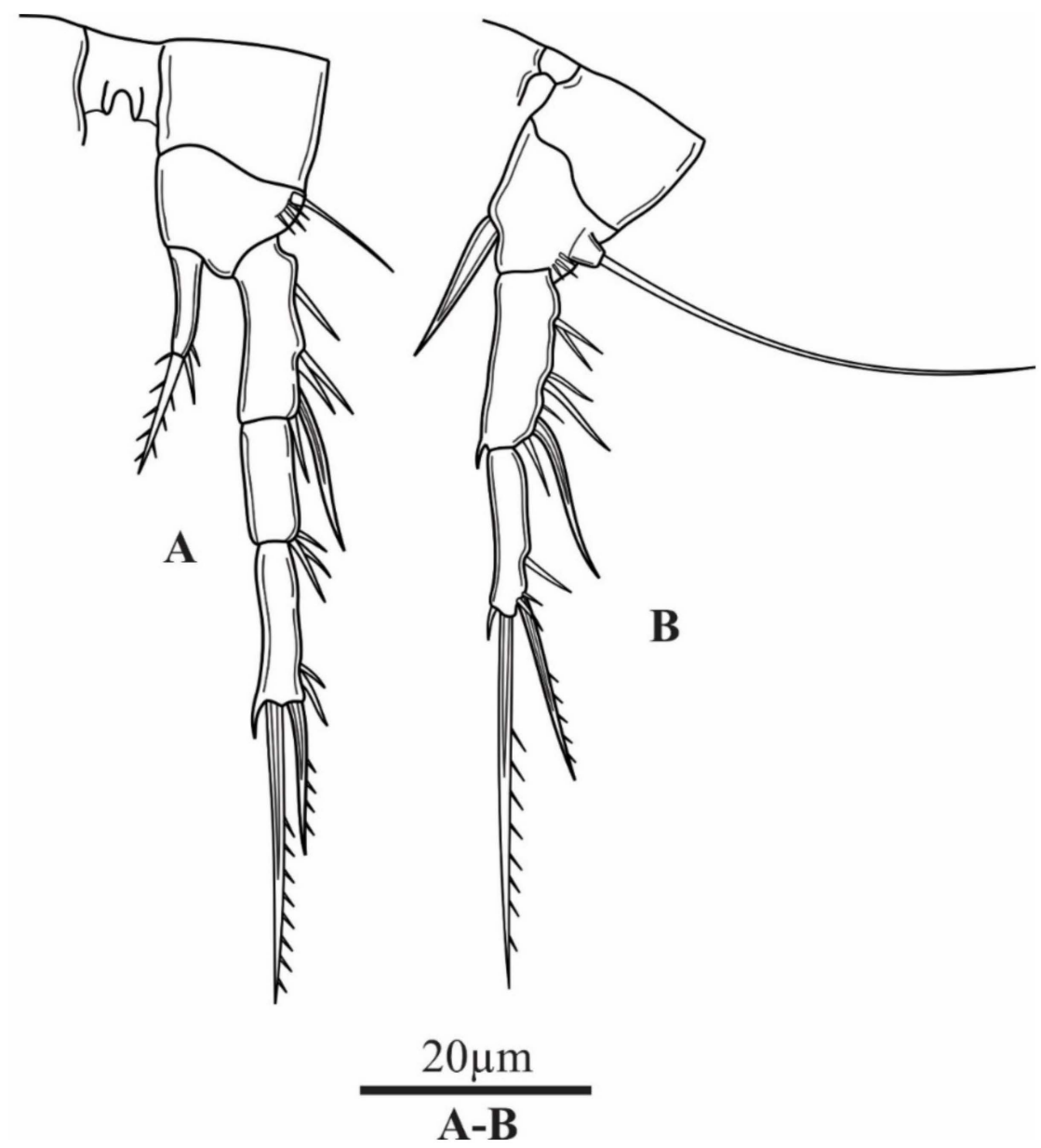

Figure 6. Parastenocaris sontraensis sp. nov. holotype female. (A), P3; (B), P4.

Antennule (Figure 8A) 7-segmented; aesthetascs on fifth and seventh segment, long, with rounded tips. Geniculation between third and fourth and between fifth and sixth segments. All setae slender and smooth. Setal formula: 0.4.3.0.1 + ae.0.9 + ae.

P3 (Figure 8B,C) basis rhomboidal, with five robust spinules on posterior surface; one long smooth outer seta. Enp reduced to one smooth seta (indicated with arrow). Exp 3-segmented, robust, curved inward. Exp-1 about 3.4 times as long as wide, with small spinule on outer distal corner; thin hyaline lamella along inner margin. Exp-2 very short, with long outer apophysis, slightly curved inward, smooth. Exp-3 as long as apophysis, with sharp tip, smooth.

P4 (Figure 9A) basis with two finger-like inner outgrowths (indicated with arrows); one straight, smooth and parallel to Enp; the second one curved, pointing outwards; with outer smooth seta. Exp 3-segmented, Enp 1-segmented. Enp blade-like, slightly shorter than Exp-1, with thin, smooth seta sub-apically. Exp with few large spinules on distal margin of all segments. Exp-1 with concave inner margin, with long spines along outer margin. Exp-2 without spine or seta. Exp-3 with one unilaterally pinnate spine sub-apically and one unilaterally pinnate spiniform seta, about 1.5 times as long as supporting segment. 


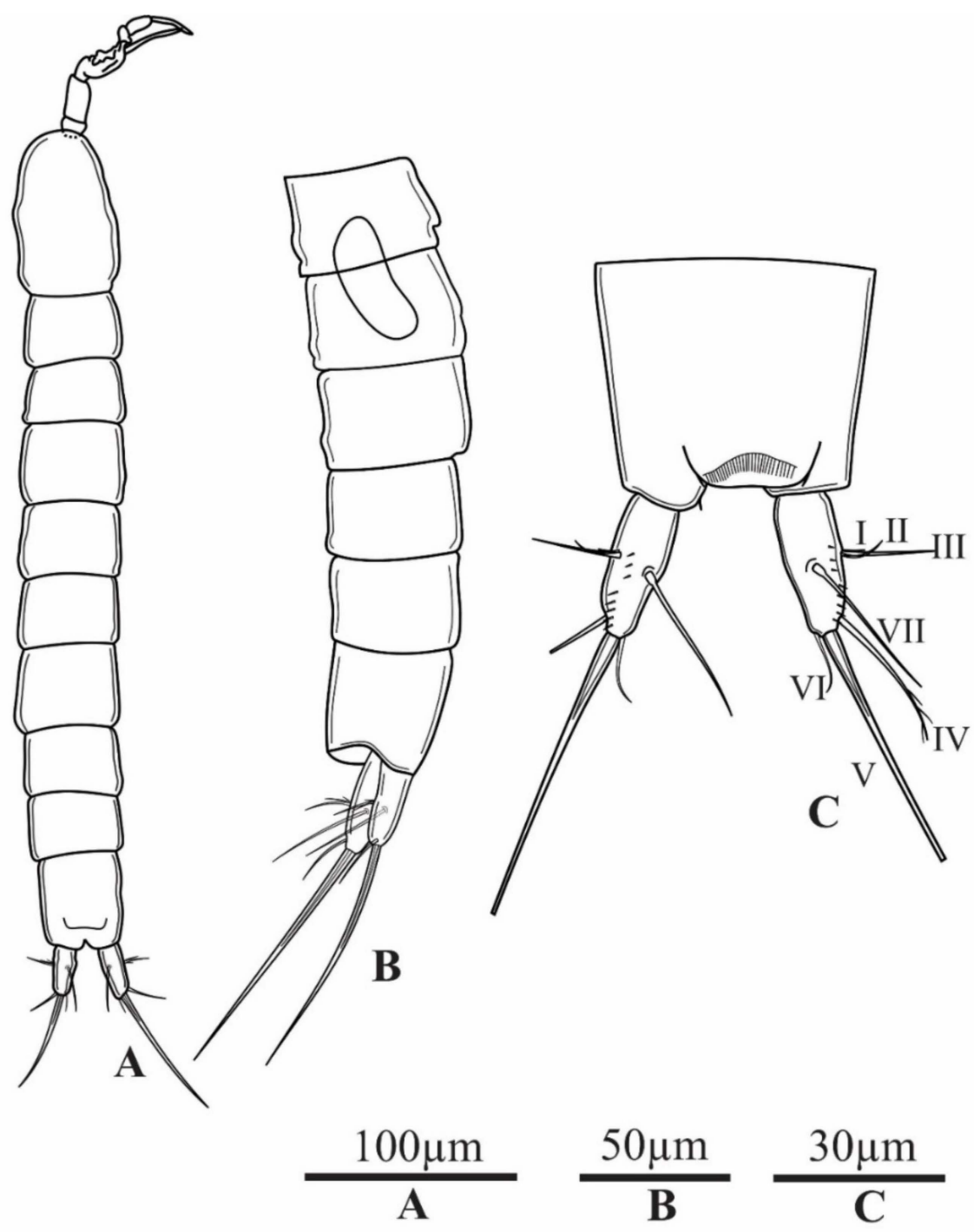

Figure 7. Parastenocaris sontraensis sp. nov. male. (A), habitus dorsal view; (B), urosome lateral view; (C), anal somite with furcal rami.

P5 (Figure 9B) baseoendopod subrectangular, with 4 smooth setae apically; outer one longest, followed by short spiniform seta and two smooth setae unequal in length; innermost seta shorter, about $1 / 3$ lengths of outer seta.

P6 (Figure 9C) reduced to two small elliptical plates fused medially; smooth, unarmed, forming simple operculum covering gonopore; fused to somite.

Variability. Except slight differences in body length, no variability was observed.

\subsection{Parastenocaris vugiaensis sp. nov.}

Type locality. Groundwater on the bank of Vu Gia river; Quang Nam province; central Vietnam; $15^{\circ} 49^{\prime} 51.2^{\prime \prime} \mathrm{N}, 108^{\circ} 11^{\prime} 19.9^{\prime \prime} \mathrm{E}$.

Material examined. Holotype: adult female (total length $440 \mu \mathrm{m}$ ), completely dissected, mounted on one slide; collected on 25 June 2019 from KC pit-hole on the bank of Vu Gia river; deposited at in the Zoological Collection of Duy Tan University, Da Nang City, Vietnam; access No.: ZC-DTU-COPEPODA-0004. Paratypes: 8 adult females stored in a plastic tube in $70 \%$ alcohol; collected on the same date and same location as holotype; access No.: ZC-DTU-COPEPODA-0005. 


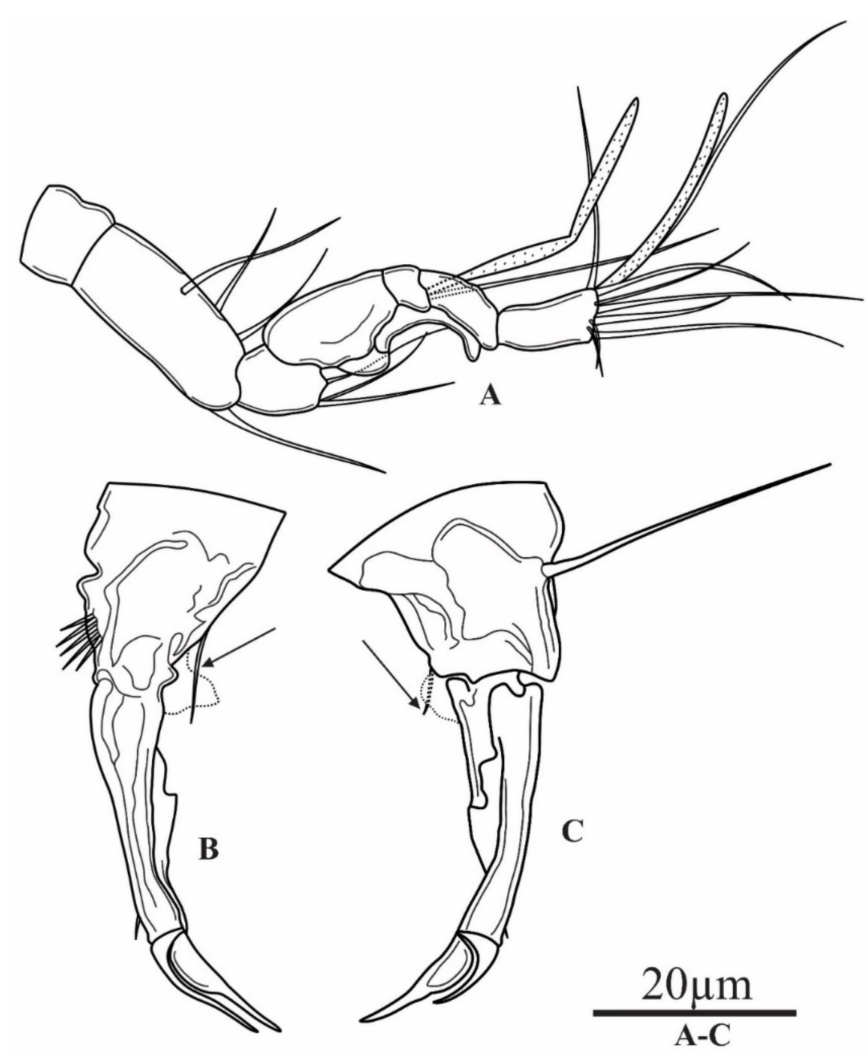

Figure 8. Parastenocaris sontraensis sp. nov. male. (A), antennule; (B), P3 posterior view; (C), P3 anterior view. The arrow indicates reduced End.

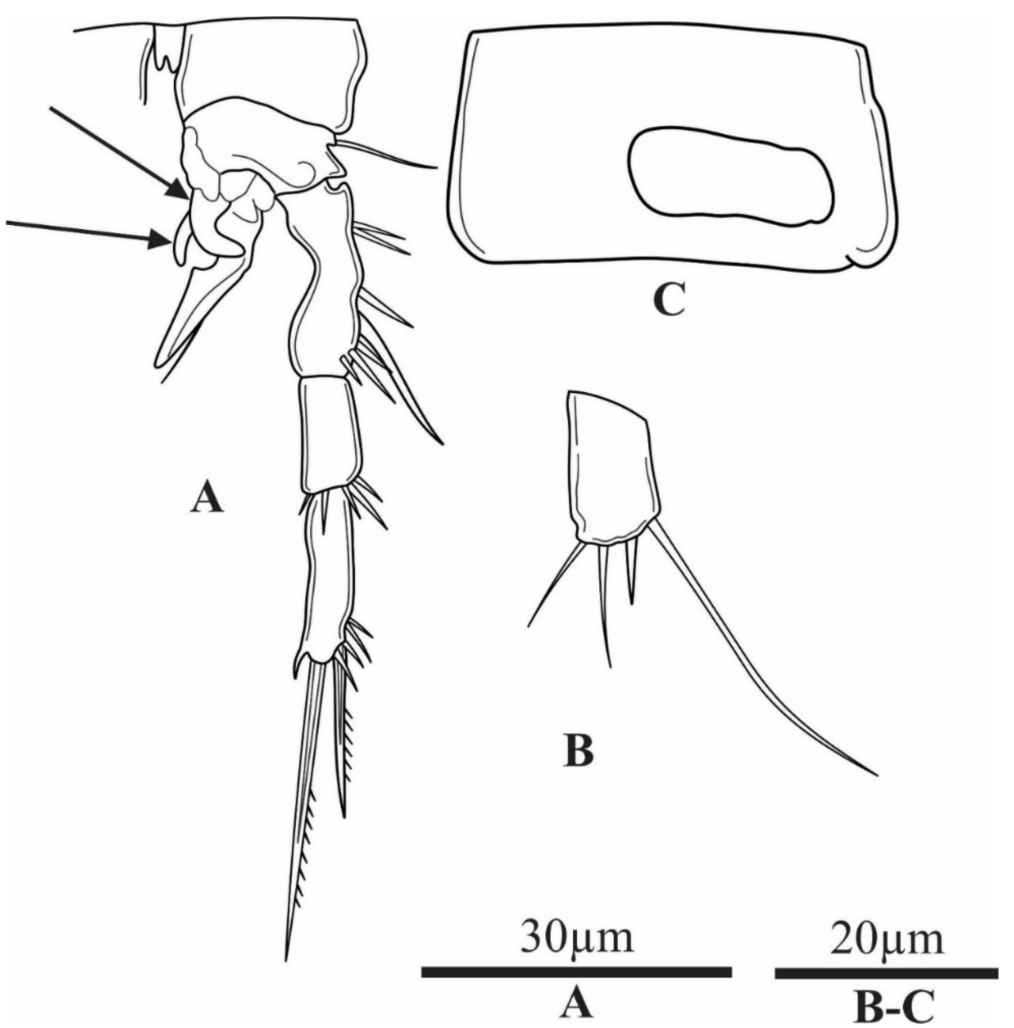

Figure 9. Parastenocaris sontraensis sp. nov. male. (A), P4; (B), P5; (C), P6. The arrows indicate outgrowth on basis. 
Etymology. The new species is named after Vu Gia river, located in Quang Nam province in the central part of Vietnam. It is in the nominative singular, gender masculine.

Description. Female (holotype); body length, measured from tip of rostrum to posterior margin of caudal rami, (excluding caudal setae) $440 \mu \mathrm{m}$. Habitus cylindrical and slender (Figure 10A,B). Prosome/urosome length ratio about 0.9; greatest width at $3 / 4$ length of cephalothorax; preserved specimens colourless. Naupliar eye and hyaline integumental window absent. Rostrum triangular, small, not reaching beyond first segment of antennule. Genital double-somite as long as wide (Figures 10A and 14B). Anal somite about 1.4 times as long as wide. Anal operculum well developed, extending beyond posterior margin of anal somite; free margin smooth, concave (Figure 10C).

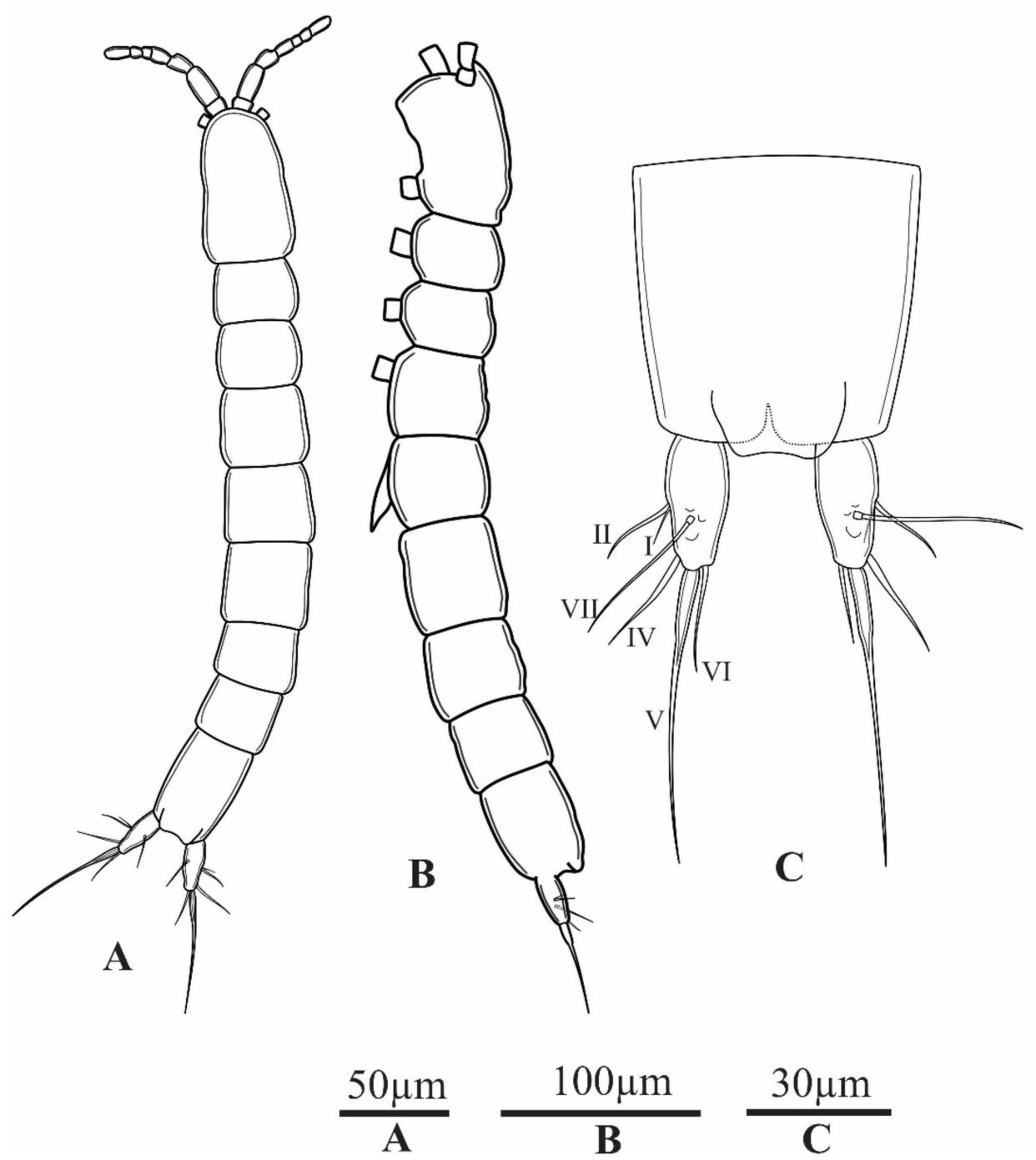

Figure 10. Parastenocaris vugiaensis sp. nov. holotype female. (A) habitus dorsal view; (B), habitus lateral view; (C), anal somite with furcal rami dorsal view.

Caudal rami (Figure 10C) elliptical, slightly divergent; ramus about 2.3 times as long as wide; with smooth inner margin. Anterolateral external accessory seta (I) shorter than width of furcal ramus, inserted medially on outer margin of ramus. Anterolateral external accessory seta (II) about twice as long as seta I, positioned next to it. Posterolateral seta (III) absent. Outer apical seta (IV) about as long as caudal ramus, smooth. Inner apical seta (V) slightly curved, stout, swollen at the base, about three times as long as caudal ramus, without breaking plane. Inner accessory seta (VI) as long as outer apical seta, 
soft, smooth. Dorsal seta (VII) longer than caudal ramus, inserted at about $1 / 2$ of its length, bi-articulated.

Antennule (Figure 11A) 7-segmented, not reaching posterior margin of cephalothorax. First segment very short; second longest. Aesthetasc on fourth segment overreaching tip of antennule, relatively slender and blunt distally. Aesthetasc on seventh segment short and slender. All setae smooth. Setal formula: 0.1.6.2 + ae.0.0.8 + ae.

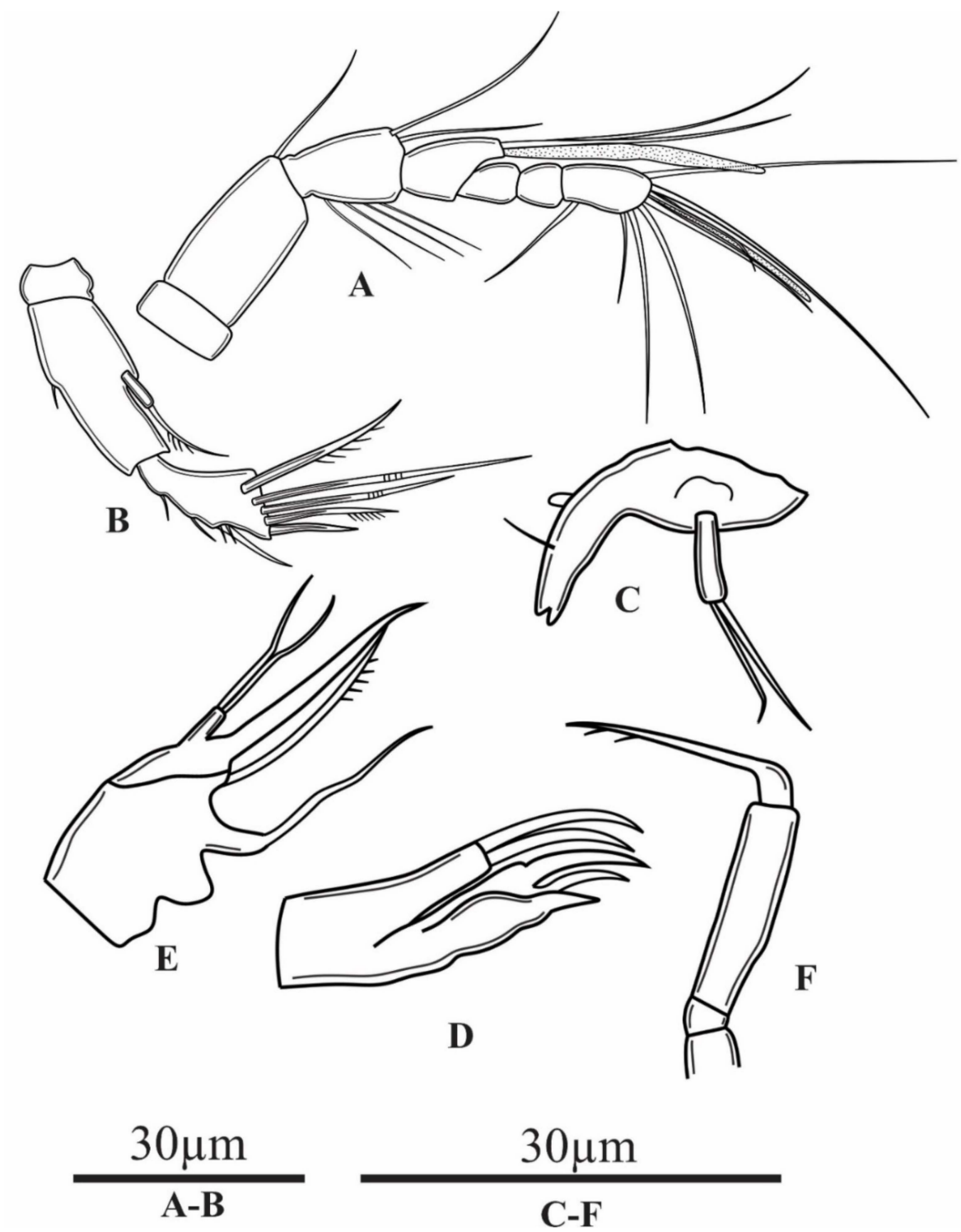

Figure 11. Parastenocaris vugiaensis sp. nov. female. (A), antennule; (B), antenna; (C), mandible; (D), maxillule; (E), maxilla; (F), maxilliped.

Antenna (Figure 11B) composed of coxa, allobasis, and one free endopodal segment. Coxa very short, unarmed. Allobasis about 2.4 times as long as wide, with one small spinule at $1 / 2$ length of inner margin. Exp 1-segmented, small, inserted at $1 / 2$ length of allobasis, with one uni-pinnate seta apically. Enp 1-segmented, about 0.7 times as long as allobasis, with a smooth spine on inner margin. Five elements apically: two geniculate setae, two uni-pinnate setae, and one spine.

Mandible (Figure 11C) with one chitinised tooth on the cutting edge and one smooth seta dorsally. Mandibular palp 1-segmented, long, cylindrical, about 3.5 times as long as wide, with two smooth setae unequal in length apically. 
Maxillule (Figure 11D) praecoxal arthrite with one distal spine. Coxal endite with two setae; basis with three setae.

Maxilla (Figure 11E) 2-segmented; syncoxa with two endites with one element apically, distal endite armed with one seta apically. Allobasis drawn out into strong claw. Enp represented by small segment, armed with two setae apically.

Maxiliped (Figure 11F) with short syncoxa, unornamented and unarmed. Basis about five times as long as wide, unarmed. Enp represented by short curved claw, swollen at base, about 1.3 times as long as basis; distal part with several spinules.

P1-P4 (Figures 12 and 13) intercoxal sclerite of all legs smooth and unarmed.

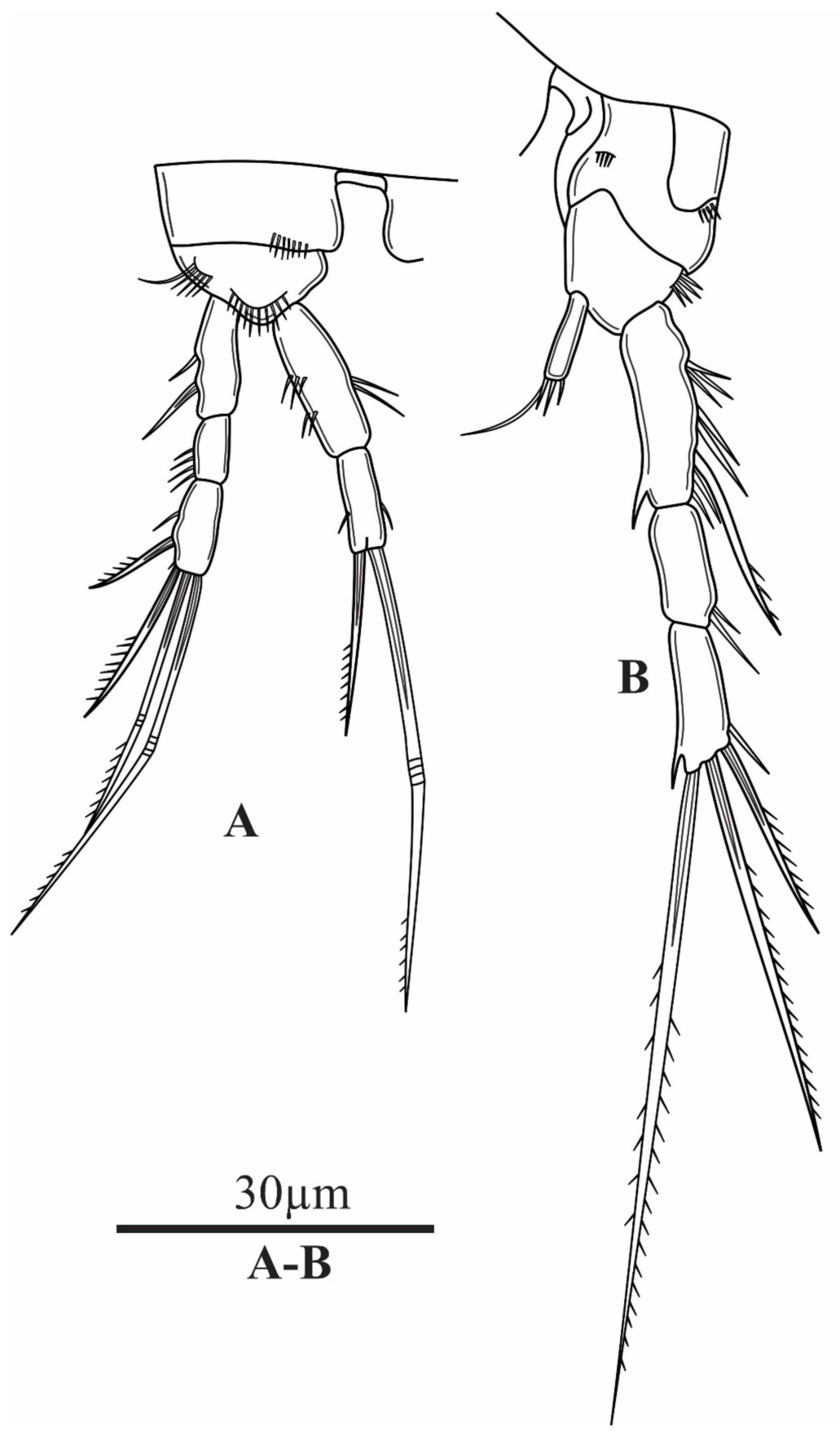

Figure 12. Parastenocaris vugiaensis sp. nov. female. (A), P1; (B), P2. 


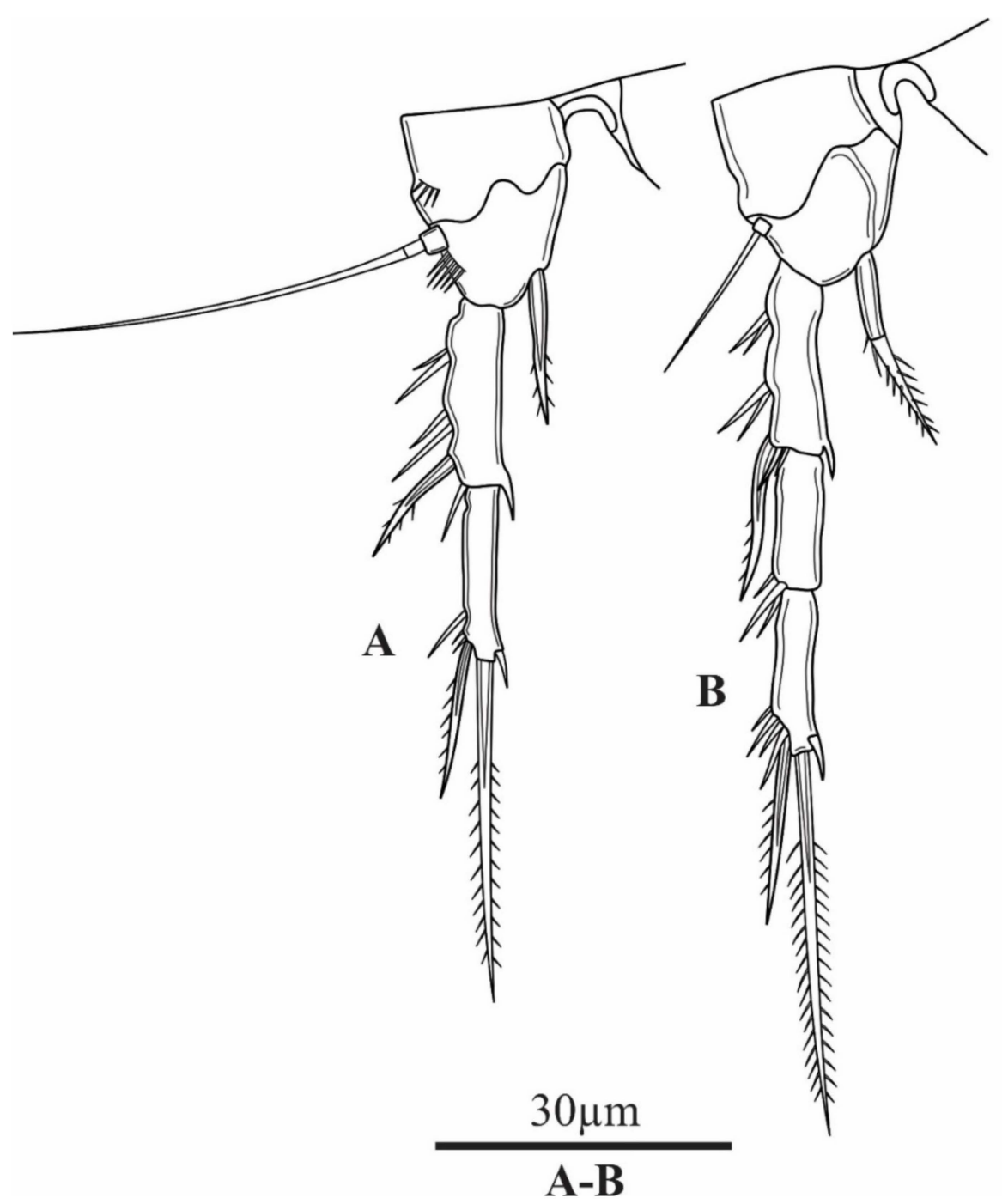

Figure 13. Parastenocaris vugiaensis sp. nov. female. (A), P3; (B), P4.

P1 (Figure 12A) coxa with one anterior row of spinules. Basis with row of spinules on anterior margin distally and on outer margin, with short, slender outer seta. Exp 3-segmented, Enp 2-segmented; Exp slightly longer than Enp. Enp-1 about 3.3 times as long as wide, with two diagonal outer rows of spinules; two slender, long spinules along margin at 1/2 length. Enp-2 with two setae apically, longer one geniculate and longer than End. Exp-1 with one strong outer spine. Exp-2 about twice as long as wide, with few outer spinules. Exp-3 about twice as long as wide, with four elements: one spine laterally, one unilaterally pinnated spine and two geniculate setae apically.

P2 (Figure 12B) praecoxa with an outer row of spinules. Coxa with one small anterior row of spinules. Basis with one row of strong outer spinules. Exp 3-segmented, Enp 1-segmented. Enp about five times as long as wide, 0.5 times as long as Exp-1, with four elements apically: three short spiniform spinules, unequal in length, and one long smooth seta. Exp-1 about four times as long as wide, with several long and robust outer spinules; one long outer spine, reaching beyond tip of Exp-2. Exp-2 about twice as long as wide, with few outer sub-distal spinules. Exp-3 slightly longer than Exp-2, with one outer spine sub-terminally; two setae apically; outer seta unilaterally pinnate, inner one bipinnate; inner apical seta about 1.5 times as long as Exp.

P3 (Figure 13A) coxa with an outer row of spinules close to margin. Basis with long outer seta; with a row of spinules below seta. Exp 2-segmented, Enp represented by single seta, and about 9.0 times as long as wide, reaching beyond half of Exp-1, with pointed tip, 
with transverse row of tiny spinules along distal part. Exp-1 about 4.5 times as long as wide, with a strong outer spine and an outer row of spinules. Exp-2 with one seta apically and one spine sub-apically; inner margin bare, but with a short spinules sub-apically.

P4 (Figure 13B) with smooth coxa. Basis with one slender, smooth seta on outer margin. Exp 3-segmented, Enp 1-segmented, slender and tapering to pointed tip and with spinulose disto-lateral margins. Exp-1 similar to Exp-1 of P3. Exp-2 about 3 times as long as wide; with some outer sub-distal spinules. Exp-3 with one short spiniform unilaterally pinnated spine sub-apically, accompanied with a group of spinules; bipinnate spiniform seta apically, slightly curved and one short inner sub-distal spinule.

P5 (Figure 14A) elongated, trapezoidal in shape, with sharply pointed tip on inner side. External margin with three smooth setae, decreasing in size, outer one longest and about 2.6 times as long as next seta.

P6 (Figure 14B) fused to somite, large, with long and robust, blade-like outer spine on each side of copulatory pore.

Male. Unknown.

Variability. Except slight differences in body length, no variability was observed.
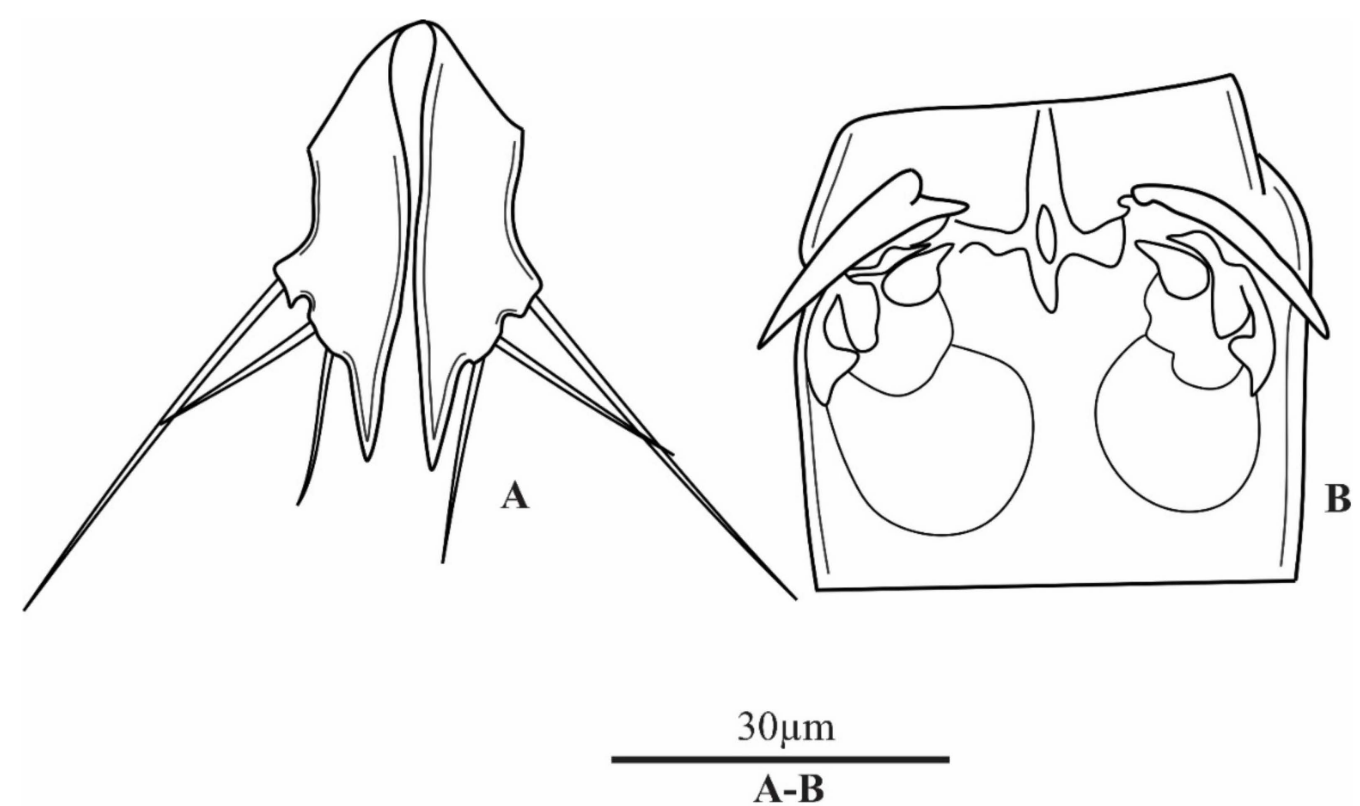

Figure 14. Parastenocaris vugiaensis sp. nov. female. (A), P5; (B), P6 and genital field.

\section{Discussion}

Only two freshwater species of the genus Parastenocaris have been described so far from Southeast Asia. From the Philippines is known P. distincta Cottarelli, Bruno, and Berera, 2006, and from Malaysia, P. arganoi Cottarelli and Mura, 1982 [2]. Parastenocaris distincta belongs to the minuta-species group. The important character of this group is that male's P4 basis has 1-5 spinules [11-13], while P. arganoi have been designed to the brevipes-group due to the morphology of a caudal ramus and P5. Parastenocaris arganoi has tapering caudal ramus and dorsal and lateral setae inserted at about half length of it. There is also bi-lobate P5 in female [12-14]. Parastenocaris sontraensis sp. nov. and Parastenocaris vugiaensis sp. nov. belong to the brevipes-group according to the following characters: (i) the female's P4 has long distally serrate endopod; and (ii) the tapering caudal ramus of both sexes have dorsal and lateral setae inserted at about mid-length of it [13].

The females of $P$. sontraensis sp. nov. and $P$. vugiaensis sp. nov. differ from the females of P. distincta and P. arganoi: (i) dorsal integumental windows are absent in both two new species but present in P. distincta; (ii) P5 of both two new species have trapezoidal shape but are rectangular in P. distincta and reduced to a lamina in P. arganoi [11,14]. 
The male of $P$. sontraensis differs from all other members of the brevipes-group by the unique character of Exp P3 with three segments in the male. P. sontraensis sp. nov. resembles to P. hinumaensis Kikuchi, 1970 in the Enp P4 armature. However, the new species differs from P. hinumaensis by the combination of the following characters: (i) Exp P3 has three segments in the male of the new species, but only two segments in P. hinumaensis; (ii) caudal rami has seven setae in both sexes in P. sontraensis sp. nov., while P. hinumaensis has only four setae (information for the latter species is only from the literature); and (iii) caudal rami of both sexes are about 2.4 times as long as wide in the new species, but 3.3 times in the male and 2.7 times in the female of P. hinumaensis [15].

$P$. sontraensis is similar to $P$. jane Karanovic, 2006 in Exp P4 armature in both sexes and concave inner margin of Exp1 P3 in the male. However, the new species can be distinguished from the latter species by several morphological characters: (i) P. sontraensis sp. nov. Exp-P3 has three segments, but there are only two segments in P. jane; (ii) caudal ramus has seven setae in both sexes in $P$. sontraensis sp. nov., but there are six elements in P. jane; (iii) in the new species caudal rami of both sexes are conical, slightly diverging, about 2.4 times as long as wide, but are cylindrical, about 2.9 times as long as wide in both sexes in P. jane [15].

In the case of P. vugiaensis sp. nov., only females were collected. The new species can be distinguished from its congeners by the following characters: (i) the elliptical shape of caudal rami, (ii) apical seta (V) with extremely bulbous at proximal region, and (iii) the length of anal operculum beyond the end of anal somite $[15,16]$. The new species is the most similar to P. tumida Kiefer, 1961 in the armature of P4 and elliptical shape of the caudal rami. However, the new species differs from $P$. tumida in the combination of the following characters: (i) P. vugiaensis has three setae on P5, but P. tumida has four setae; (ii) caudal ramus of the new species has six setae, while $P$. tumida has seven setae; (iii) anterolateral external accessory seta (I), anterolateral external accessory seta (II) and posterolateral seta (III) are in P. tumida at about 2/3 of external margin length, while insertion of mentioned three setae in the new species are at about $1 / 2$ length of furcal ramus.

Only 14 stygobiotic Copepoda are now known from Vietnam: eleven species from caves and three from hyporheic habitats (Figure 15). Of ten cave-dwelling species, six species, i.e. Bryocyclops anninae (Menzel 1926); Nannodiaptomus phongnhaensis Dang and Ho, 2000; Nannodiaptomus haii Tran and Brancelj, 2017; Pseudograeteriella longifurcata (Tran and Chang, 2012); Pseudograeteriella longiaesthetascus Sanoamuang, Boonyanusith and Brancelj, 2019; Mesocyclops sondoongensis Tran and Hołynska, 2015 have been so far recorded from caves in Quangbinh province in central Vietnam. Five other species have been recorded in caves of three different provinces in north Vietnam, including Hadodiaptomus dumonti Brancelj, 2005 in Hanoi, Nitocra vietnamensis Tran and Chang, 2013 and Microarthridion thanhi Tran and Chang, 2013 in Ninhbinh province, Elaphoidella vietnamica Borutzky, 1967 and Attheyella (Canthosella) vietnamica Borutzky, 1967 in Hoa Binh province. The A. (C.) vietnamica has been also recorded in Noen Maprang district, Phitsanulok province, Thailand. The first record of a copepod in the hyporheic habitats was Metacyclops amicitiae Kołaczynski, 2015 in Vinh Phuc province, while two new species, P. sontraensis sp. nov and P. vugiaensis sp. nov., were collected in Da Nang city and Quang Nam province, respectively, in central Vietnam.

In Vietnam, there are about $60,000 \mathrm{~km}^{2}$ of karstic areas, which represents $18.1 \%$ of the total country area, and with several hundred explored caves, the country is first place within Southeast Asian countries [17]. At the same time, Vietnam has a well-developed river network, which potentially presents ecologically diversified hyporheic habitats, too. Therefore, there is potential for recording new stygobiotic copepod, both from fractured (i.e., karstic) or unconsolidated (i.e., alluvial/hyporheic) habitats. High potential for new species from unconsolidated habitats is supported by: (i) so far, only one species was recorded there (Metacyclops amicitiae Kołaczynski, 2015) [18], but (ii): during our first sampling of hyporheic zone of two rivers, we found several new stygobiotic species besides the species of Parastenocaris presented herein (other species will be described elsewhere). 


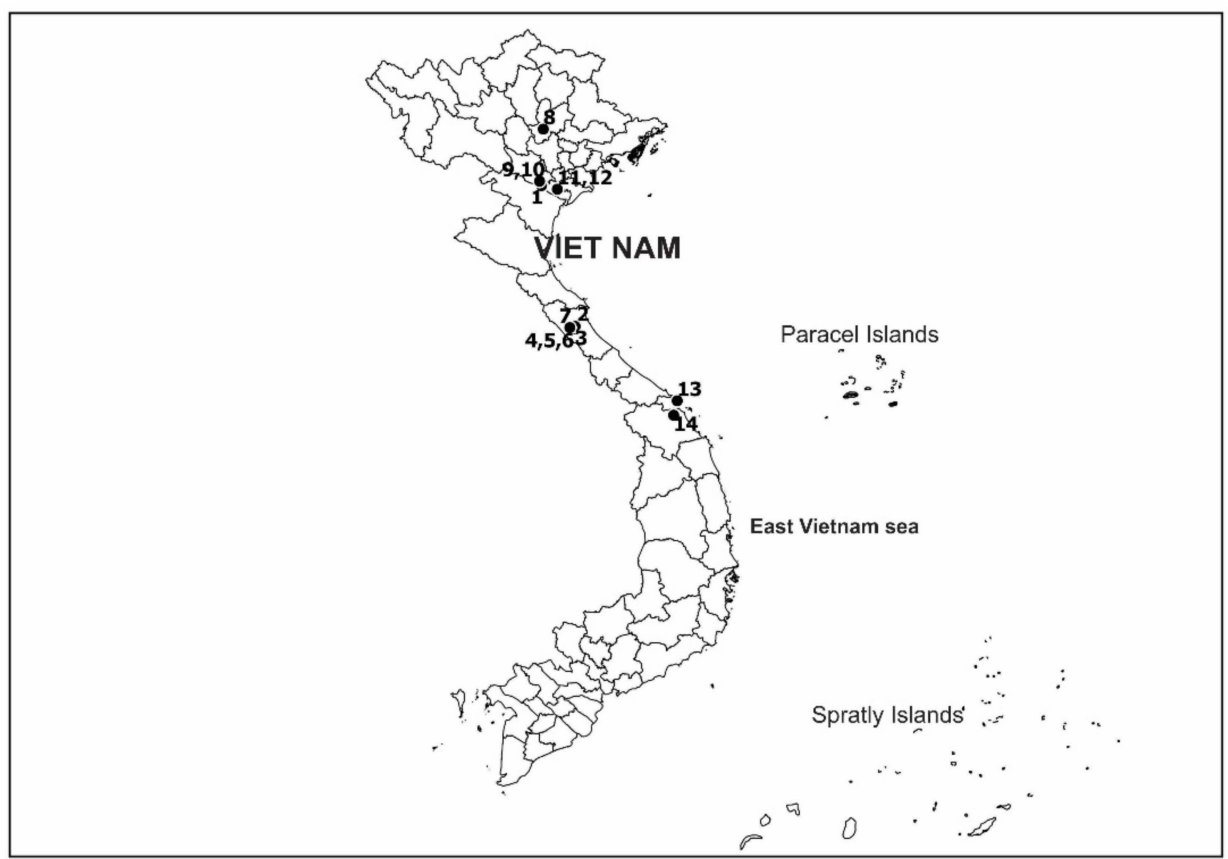

Figure 15. Map showing distribution of: 1. Hadodiaptomus dumonti, 2. Nannodiaptomus phongnhaensis, 3. Nannodiaptomus haii, 4. Bryocyclops anninae. 5. Pseudograeteriella longifurcata, 6. Pseudograeteriella longiaesthetascus, 7. Mesocyclops sondoongensis, 8. Metacyclops amicitiae, 9. Attheyella (Canthosella) vietnamica, 10. Elaphoidella vietnamica, 11. Microarthridion thanhi, 12. Nitocra vietnamensis, 13. Parastenocaris sontraensis sp. nov., and 14. Parastenocaris vugiaensis sp. nov.

From geographic as well as ecological aspects, Vietnam could be compared with near-by Thailand. It extended in a rather narrow strip in N-S direction for about $1600 \mathrm{~km}$ and covering subtropical and tropical climate $\left(23^{\circ} \mathrm{N}-8^{\circ} \mathrm{N}\right)$, with rather modest altitude differences (about $1600 \mathrm{~m}$ ) from the highest peak to the sea level. Many new stygobiotic species of Copepoda have been recorded in Thailand since 2010 as a result of intensive sampling in the caves [19-25]. The same is expected for Vietnam when intensive work on groundwater habitats starts.

Author Contributions: Conceptualization, N.-S.T., A.B. and M.T.-D.; methodology, N.-S.T., A.B. and M.T.-D.; data curation, N.-S.T. and M.T.-D.; software: N.-S.T. and M.T.-D.; supervision: A.B. and N.S.T.; validation: A.B. and N.-S.T.; writing—original draft: N.-S.T. and M.T.-D.; writing-review and editing: N.-S.T. and A.B. All authors have read and agreed to the published version of the manuscript.

Funding: This research was funded by Funds from the Ministry of Education and Training, Vietnam; grant number B2019-DNA-05 for both Vietnamese authors (N.-S.T and M.T.-D). The Slovenian author (A.B.) acknowledge the financial support from the Slovenian Research Agency (ARRS; research program P1-0255).

Institutional Review Board Statement: The research did not carry any potential harm for humans. This study addressed the taxonomy of two new species of free-living copepods found in groundwater habitats. In addition, the free-living copepods of this research are not involved in the "circular on good laboratory practice" issued by the Ministry of Health, the Vietnamese government.

Informed Consent Statement: Not applicable.

Data Availability Statement: Not applicable.

Acknowledgments: The first author would like to thank the Faculty of Biology and Environmental Science at the University of Science and Education (UDN) for providing us with the research facilities.

Conflicts of Interest: The authors declare no conflict of interest. 


\section{References}

1. IUCN. Ecological Survey of the Mekong River between Louangphabang and Vientiane Cities; IUCN Lao PDR: Vientiane, Laos, 2013; pp. 1-241.

2. Brancelj, A.; Boonyanusith, C.; Watiroyram, S.; Sanoamuang, L. The groundwater-dwelling fauna of Southeast Asia. J. Limnol. 2013, 72, e16. [CrossRef]

3. Lopez, M.D.; Papa, R.D.S. Diversity and distribution of copepods (Class: Maxillopoda, Subclass: Copepoda) in groundwater habitats across South-East Asia. Mar. Freshw. Res. 2020, 71, 374-383. [CrossRef]

4. Gaviria-Melo, S.; Walter, T.C. Parastenocarididae Chappuis, 1940. World of Copepods Database 2014. Walter, T.C., Boxshall, G., Eds. Available online: http:/ / www.marinespecies.org/copepoda/aphia.php?p=taxdetails\&id=115170 (accessed on 10 August 2021).

5. Ranga Reddy, Y.R. Parastenocarididae (Crustacea, Copepoda, Harpacticoida) of India: Description of Parastenocaris mahanadi n sp., and redescription of P. curvispinus Enckell, 1970 from hyporheic habitats. Zootaxa 2007, 26, 1-26. [CrossRef]

6. Chappuis, P.A. Harpacticides psammiques récoltés par Cl. Delamare Deboutteville en Mediterranée. Vie Milieu 1954, 4, 259276.mm.

7. Brancelj, A. Biological sampling methods for epikarst water. In Epikarst; Jones, W.K., Culver, D.C., Hernan, J.S., Eds.; Karst Waters Institute: Sheperdstown, WV, USA, 2004; pp. 99-103.

8. INKSCAPE 2021. Available online: https:/ /inkscape.org/ (accessed on 20 September 2021).

9. Huys, R.; Boxshall, G.A. Copepod Evolution; The Ray Society: London, UK, 1991; 468p.

10. APHA; AWWA; WPCF. Standard Methods for the Examination of Water and Wastewater, 16th ed.; American Public Health Association: Baltimore, MD, USA, 1985; 1268p.

11. Cottarelli, V. A new freshwater harpacticoid from Philippines: Parastenocaris distincta sp. nov. (Copepoda, Harpacticoida). Zootaxa 2006, 1368, 57-68. [CrossRef]

12. Lang, K. Monographie der Harpacticiden; Nordiska-Bokhandeln: Stockholm, Sweden, 1948; Volume 1-2, 1682p.

13. Karanovic, T. Two new subterranean Parastenocarididae (Crustacea, Copepoda, Harpacticoida) from Western Australia. Rec. West. Aust. Mus. 2005, 22, 353. [CrossRef]

14. Cottarelli, V.; Mura, G. Parastenocaris arganoi n. sp., a new troglobian species from Malaysia. Malay. Nat. J. 1982, $35,65-71$.

15. Karanovic, T.; Lee, W. Invertebrate Fauna of the World (Arthropoda: Crustacea: Harpacticoida: Parastenocarididae), parastenocaridid copepods. Natl. Inst. Biol. Resour. Minist. Environ. 2012, 219, 1-232.

16. Schminke, H.K.; Notenboom, J. Parastenocarididae (Copepoda, Harpacticoida) from the Netherlands. Bijdragen Dierkunde 1990, 60, 299-304.

17. Day, M.J.; Urich, P.B. An assessment of protected karst landscapes in Southeast Asia. Cave Karst Sci. 2000, 27, 61-70.

18. Kołaczyński, A. A new species of Metacyclops from a hyporheic habitat in North Vietnam (Crustacea, Copepoda, Cyclopidae). ZooKeys 2015, 522, 141-152. [CrossRef] [PubMed]

19. Brancelj, A.; Sanoamuang, L.-O.; Watiroyram, S. The First Record of Cave-Dwelling Copepoda from Thailand and Description of a New Species: Elaphoidella namnaoensis n. sp. (Copepoda, Harpacticoida). Crustaceana 2010, 83, 779-793. [CrossRef]

20. Watiroyram, S.; Brancelj, A.; Sanoamuang, L. A new Bryocyclops Kiefer (Crustacea: Copepoda: Cyclopoida) from karstic caves in Thailand. Raffles Bull. Zool. 2012, 60, 11-21.

21. Watiroyram, S.; Brancelj, A.; Sanoamuang, L. Two new stygobiotic species of Elaphoidella (Crustacea: Copepoda: Harpacticoida) with comments on geographical distribution and ecology of harpacticoids from caves in Thailand. Zootaxa 2015, 3919, 81-99. [CrossRef] [PubMed]

22. Watiroyram, S.; Brancelj, A. A new species of the genus Elaphoidella Chappuis (Copepoda, Harpacticoida) from a cave in the south of Thailand. Crustaceana 2016, 89, 459-476. [CrossRef]

23. Watiroyram, S.; Sanoamuang, L.; Brancelj, A. Two new species of Elaphoidella (Copepoda, Harpacticoida) from caves in southern Thailand and a key to the species of Southeast Asia. Zootaxa 2017, 4282, 501. [CrossRef]

24. Boonyanusith, C.; Sanoamuang, L.-O.; Brancelj, A. A new genus and two new species of cave-dwelling cyclopoids (Crustacea, Copepoda) from the epikarst zone of Thailand and up-to-date keys to genera and subgenera of the Bryocyclops and Microcyclops groups. Eur. J. Taxon. 2018, 431, 1-30. [CrossRef]

25. Sanoamuang, L.; Boonyanusith, C.; Brancelj, A. A new genus and new species of stygobitic copepod (Crustacea: Copepoda: Cyclopoida) from Thien Duong Cave in Central Vietnam, with a redescription of Bryocyclops anninae (Menzel, 1926). Raffles Bull. Zool. 2019, 67, 189-205. [CrossRef] 